Original Research Paper

\title{
The European Miracle \\ Psychological Stages and the Origin of Modern Society
}

\author{
${ }^{1}$ Georg Oesterdiekhoff, ${ }^{2}$ Jörn Rüsen and ${ }^{3}$ Hans-Jürgen Hummell \\ ${ }^{1}$ Department of Sociology, Karlsruhe Institute for Sociology, Germany \\ ${ }^{2}$ Department of History, Kulturwissenschaftliches Institut, Germany \\ ${ }^{3}$ Department of Sociology, University Duisburg-Essen, Germany
}

\author{
Article history \\ Received: 19-02-2020 \\ Revised: 23-04-2020 \\ Accepted: 12-05-2020 \\ Corresponding Author: \\ Georg Oesterdiekhoff \\ Department of Sociology, \\ Karlsruhe Institute for \\ Sociology, Germany \\ Email: oesterdiekhoff@t-online.de
}

\begin{abstract}
The idea that the rise of modern, industrial society originates in psychological advancements is to find among classic authors of sociology and history such as Comte, Elias and Lamprecht and more recently described by Habermas. It will be shown that central transformations within sciences, industrial economy, political structures, Enlightenment, humanitarian revolution, law, painting, music and literature having taken place during the emergence of modern society actually originate in psychological stage advancements. Thus, there is a deep connection between psychological stages on the one side and historical transformations leading to modern society on the other side. It is therefore necessary to combine Piagetian psychology with historical data and sociological considerations.
\end{abstract}

Keywords: Psychological Stages, Social Transformations, Modern, Industrial Society, Modern Europe, Rise of the West

\section{Introduction}

Modern, industrial society started in Britain after 1750 roughly, followed by continental Europe from about 1830 onwards. North America, Russia and Japan joined this transformation only a few decades later. Modern, industrial society consisted mainly of breakthroughs in physical sciences and engineering, industrial technologies, foundation of factories and mining companies, increase of agricultural productivity, expansion of secondary and tertiary sector, introduction of compulsory school attendance, decline of birth rates, Enlightenment, extension of public functions, constitutional state, parliamentarianism and later on frequently democratic structures.

Modern, industrial society did not only originate completely new structures but abolished also structures that existed for long, since antiquity or even Stone Ages. It surmounted so for the first time in history the magicalanimistic worldview with its belief in witches, sorcerers, ghosts and natural gods. It erased the belief in myths and collective fantasies and weakened the power and impact of religion. It replaced the cruel punishment law of premodern society, lasting back to the Stone Ages, by the system of imprisonment. It abolished slavery, feudalism and other forms of serfdom by the instalment of liberty rights. Later on it forbade the duel culture and physical violence against women, children and dependent persons. It strengthened the rights of workers and minorities and protected poor persons, children and animals from maltreatment.

Thus, modern, industrial society has attained a new stage of culture and civilization, unparalleled and unique in the humankind's history. Therefore, modern society seems to have not only more economic, technological and scientific power and achievement but has also attained higher stages in civilization, education, morals and manners. Consequently, the essence of modern society is not capitalism, as Marx and his followers have believed. Its essence rather is civilization, as already Lubbock, Darwin and Elias surmised.

From a certain viewpoint, it is possible to group the existing theories that try to explain the rise of modern, industrial society into two classes, the materialisticeconomic-institutional and the socio-psychological theory type (Oesterdiekhoff, 2013a: 29-48; 2011: 25-39). To the first type belong economic theories that focus capital investments, free markets, or free property rights as causes to the rise of the (Western) capitalism. To the same group belong also Marxian ideas of colonialism and the theory of the world system with its peripheries and centers, that is, theories that regard international inequalities and exploitation of the South as central to the explanation related. To this group have to be added also sociological theories that earmark class 
constellations, state structures, or struggles for power (e.g., Diamond, 1998; Frank and Gills, 1993; Jones, 1987; North and Thomas, 1973; North, 1990; Sanderson, 1999; Smith, 1776; Wallerstein, 1974; Wittfogel, 1957).

One of the problems of these by now prevailing approaches is, even at first glance, that they cannot really cover and earmark the transformations in morals, manners and politics, the explosion in sciences, philosophy, literature and arts. The Marxian distinction of Basis and Überbau is superficial as the scientific revolution is even central to the industrial technologies, industrial revolution and economic growth. It appears as rather more convincing to conceive the industrial uprise as being only one manifestation of the increase of mental abilities to that likewise belong the transformations in politics, morals, education, arts, music, literature and manners. Accordingly, research has shown that investments, property rights, class constellations, or power conflicts did not trigger the beginning of modern, industrial civilization (Pomeranz, 2001; Mokyr, 1990; Jacob, 1997; Landes, 1998; Oesterdiekhoff, 2005; 2007; 2011; 2013a; 2014a).

The socio-psychological theories have therefore combined institutional and psychological factors with regard to the explanatory problem mentioned. They exist in weaker forms when regarding psychological phenomena as being only additional factors and when conceiving only some superficial elements (discipline, empathy, flexibility, achievement motivation, etc.) of the (modern) mentality and not their very fundamentals (e.g., Weber, 1987; Lerner, 1958; Inkeles, 1974; Landes, 1969). Intermediary stages may be reached when the authors refer to the comparison of ontogeny and history on a substandard level, as Comte, Lubbock and Elias (1982) had done.

It will be demonstrated here that the developmental approach discloses both the origins and the nature of modern, industrial society. It can be shown that the modern humankind has developed the adolescent stage of formal operations stepwise during the past few centuries, while the premodern humankind stayed on psychological stages that are nowadays to find only among children. Only some percentages of people attained intermediary stages. Premodern humans differ from children by experience and knowledge but not by their psychological stage structures. Developmental and cross-cultural psychology has evidenced these facts in a clear and encompassing way. Therefore, this kind of developmental theory is the strongest version within the range of the socio-psychological theories and is the key to understand the rise of modern, industrial society. As already mentioned, Comte, Lubbock and Elias expressed this idea on a yet scanty basis, Schultze (1900), Ziégler (1968) and Habermas (1989) elaborated this approach more distinctly. The structural-genetic theory programme, however, has delivered a complete theory of modern society in terms of developmental psychology (Oesterdiekhoff, 2007; 2014a; 2014b). It will be shown here that every manifestation of modernization in sciences, economics, politics, law, morals, arts, literature, etc. has to be explained in terms of developmental psychology. The rise of modern society simply is a manifestation of higher psychological stages of the people.

It is necessary to outline here the methodology underlying the whole framework and argumentation. Developmental and cross-cultural psychology is used to reconstruct the history of sciences, industrial economy, Enlightenment, humanitarian revolution, democracy and fine arts. Cross-cultural data concerning human development are applied to phenomena usually described by ethnographic and historical methods and considerations only. It is shown that by using these empirical data it is possible not only to describe the historical phenomena (as being done usually by historians and sociologists) but to explain them. Humans had to elevate the formal operational stage to be able to create sciences, industrial economy, enlightened morals, ideas and values, democracy and modern arts. Thus, the systematic application of cross-cultural Piagetian data, won by empirical surveys, to the historical development of mind during the early modern times was necessary to find the key to the explanation of these historical developments. Insofar the approach consists of the combination of empirical data, won both by child and cross-cultural psychology, and notions won by history, ethnology and sociology.

\section{Developmental, Historical and Cross- Cultural Psychology}

Many representatives or even founders of the human and social disciplines during the 19th and early 20th century discovered similarities between children and premodern adults. Likewise most psychoanalysts and almost every (!) founder and early representative of child or developmental psychology described these correspondences mentioned. Schultze (1900) and Werner (1948) dedicated whole monographs to them. Jean Piaget described these parallels in most of his writings (Ibarra, 1994). He discriminated four stages of human development. The sensorymotor stage of the suckling is followed by the preoperational stage, dominant between $1 ; 6$ and 8 years roughly. The preoperational stage is positively characterized by the acquisition of language and reasoning, anticipation and memory and negatively by the dominance of magic and superstition and by lack of abstraction and logic. It is the stage that mainly corresponds to the mind of greater parts of premodern humankind. The third stage, that of the concrete operations, unfolds between the 6th and the 12th year of 
age. It entails some forms of logic and abstractions regarding visual objects and erases greater parts of the magical-animistic worldview. It was first established by the Ionian philosophers, as Piaget described. The fourth stage, the stage of formal operations, manifests stepwise and increasingly between the 10th and the 25th year of age. It is divided in the substages $\mathrm{A}$ and $\mathrm{B}$, with the latter one coming into existence with 15 years roughly. It entails combinatorial, experimental, logical and theoretical-systematic reasoning abilities. The adolescent understands and develops coherent theories and conquers higher stages in morals and politics. The formal operational stage erases the last rests of the childlike magical-animistic and fairy tale worldview. According to Piaget, the formal operational stage, now defining the average adult in modern societies, developed historically first among scientists of the 17 th century. It spread stepwise from these elites through some broader social strata to the whole society, defining the normal course of every modern human being not before the advanced 20th century (Piaget and Inhelder, 1969).

Piagetian cross-cultural psychology researched among ethnicities, social milieus and nations around the globe since more than 80 years by now. More than 1.000 tests concerning stage assignments have been applied to people from every race and nation. It was found that people living in archaic, traditional, illiterate or underprivileged social milieus stay on preoperational or concrete operational stages, or on intermediary stages covering the two mentioned. In any case premodern people do not reach the formal operational stage, that is, developmental ages of modern adolescents. Both test results and ethnographic literature clearly show that the biggest part of the premodern humankind from Stone Ages to the eve of the modern world did not develop beyond the preoperational stage. People living in modern societies have been climbing on operational stages stepwise from generation to generation over the past centuries. Only the 20th century conveyed the formal operational stage to being the modal stage of the people (Ashton, 1975; Dasen and Berry, 1974; Dasen, 1977; Luria, 1982; Mogdil and Mogdil, 1976; Oesterdiekhoff, 2016c; 2017a; Lévy-Bruhl, 1923; 1985). Thus, recent cross-cultural empirical research confirmed the early considerations of Schultze (1900), Werner (1948) and Wallon (1928), but also of Elias (1982), Comte, Lubbock and others (Weiler, 2011).

The tests found the parallels between children and premodern adults regarding the whole range of psychological life and world understanding, including language, logic, physics, social affairs, law, politics, morals, religion, etc. (Oesterdiekhoff, 2013a; 2011; 2009a; Mogdil and Mogdil, 1976; Ashton, 1975). There is not one phenomenon typical for the child's mind that is not also a feature typical for premodern adults, down to smallest details such as understanding of shadows, waves, movements of projectiles, etc. The parallels are therefore not context-dependent or area-limited but are all-encompassing and deep-rooted. Therefore the conclusion is inevitable that premodern peoples stay on psychological stages of children (or some smaller percentages on intermediary stages) but differ from them in knowledge and life experience. Peoples living in modern societies stay on stages of adolescents and differ from them likewise by knowledge and experience. However, modern peoples separate from premodern ones by several developmental years, usually 5 to 10 (Oesterdiekhoff, 2016a; 2016c; 2017a). That fact explains the huge differences in mind and behaviour ethnography has detailed during the last three centuries (Lévy-Bruhl, 1923; 1985).

The causes to these divergences cannot be racialbiological but only cultural-educational factors, as crosscultural research can clearly show. Children very young when moving from archaic milieus to modern settlements develop divergently from their parents (Mogdil and Mogdil, 1976; Dasen, 1977). The recent rise of modern society on a global scale has caused stage advancements within a few generations more or less nearly everywhere. Premodern society usually has not the means to force psychological development beyond the 10th developmental year, often not beyond the 7 th developmental year. Conversely, modern society attracts and forces children from their very first days to run through the stages. Socialisation stimuli and open or closed developmental windows are the concepts to describe the possibilities to attain divergent developmental stages (Oesterdiekhoff, 2009a; 2011; 2012; 2016a; 2016c; Werner, 1948).

Against this background it is necessary to rewrite history, the history of language, population, economics, society, culture, sciences, philosophy, politics, law, religion, morals, violence, manners, etc. Smaller or greater parts of this work have been already accomplished (Habermas, 1989; Ziégler, 1968; Schultze, 1900; Oesterdiekhoff, 2011; 2009a; 2013a; 2014d; $2014 \mathrm{e})$. The history of sciences is rewritten in terms of developmental stages (Piaget and Garcia, 1989), likewise the history of some medieval cultural patterns (Radding, 1985), the Maya and Aztec culture (Ibarra, 2007), the history of painting (Gablik, 1976), the history of literature (LePan, 1989) and further the history of culture, religion, philosophy, law, economics, language, politics and morals (Oesterdiekhoff, 2009a; 2011; 2013a; 2014c; 2014d; 2014e; 2015; 2016b; 2017b; 2019).

A central part within this transfer work is to explain both the rise and nature of modern society in terms of developmental stages. Therefore, the article will reconstruct the modern transformations of sciences, industry, Enlightenment, democracy, law, humanism, 
music, literature, arts and international power against the knowledge developmental psychology provides. Thus, modern society is essentially the societal manifestation of certain psychological stage advancements.

\section{Sciences}

Without the emergence of the sciences during the 17 th century, the sciences "im eigentlichen Sinne", the rise of modern, industrial society wouldn't have been possible. It can be shown, however, that the emergence of the formal operational stage was the cause to the rebirth of the sciences during that era. That alone discerns the decisive role of developmental psychology in explaining the rise of industrial society.

The new sciences started more or less with the experiments of Galileo Galilei during the 1590ies, reaching its early peak with the Principia of Isaac Newton in 1687. The scientists of the 17th century resorted to the achievements of the Hellenistic epoch that had already developed the sciences to a considerable rate possibly not fully recognized by now. Possibly was Newton the first to parallel or to surmount scientists like Archimedes, Hipparchos or Philon. Some authors (Bailey, 1994) maintain that already the Mesopotamians had the mathematical knowledge of Euclid around 2.000 B. C. However, what is known today is that the Hellenistic era was the only era in antiquity with developed sciences comparable to Europe around 1700 roughly. The Greeks themselves believed though that they all had learned from Egypt and Mesopotamia. With the breakdown of the Hellenistic sciences after the Roman conquest of the Eastern Mediterranean ancient civilization lost the formal operational stage already attained by their small circle of scientists. Neither the Romans nor medieval Europeans were intellectually capable to understand the research conducted by the Hellenists. Leonardo da Vinci and Galilei belonged to the first group of those who succeeded in understanding the documents and in resuming the ancient research (Russo, 2005).

The loss of formal operational stage in the ancient intellectual elite let the childlike mythological and magical-animistic worldview reappear, as it dominated in the whole premodern world apart from the short Hellenistic revolution. The intellectuals of the Middle Ages adhered to theological and philosophical theories, originating in the preoperational stage. They were not true scientists in consequence of their lowered psychological stage. They understood physics against the background of animistic schemata and magical influences, as children do by their tenth year at the latest. For example, their theory of movement completely bases on the animism of the child. They did not understand physical laws on the formal operational stage level but as the child understands them, namely as a confusion of will and moral, as moral and judicial laws the phenomena have to obey (Oesterdiekhoff, 2017c; 2013a: 287-329; Piaget and Garcia, 1989; Piaget, 1975).

The child's animism and magic bases and structures the medieval disciplines. Medieval astronomy understands the celestial movements as intended movements of living beings, seeing the stars and planets as persons or gods wandering their circles. More, the persons walk in the heavens because it is their duty to march, as soldiers have to do when their officers call them. This idea governing the child's understanding of astronomy was shared by the astronomers by the days of Johannes Kepler. It was Isaac Newton who developed astronomy as being a true science, thus elevating it to the formal operational stage.

The same process took place in chemistry. The medieval chemist regarded the chemical elements as alive and tried to influence them by magical means. He hoped to influence them by his words and to alleviate their position in the cosmic hierarchy and to receive from them some goods in exchange for his pleasant conduct. Alchemy transformed to chemistry at that moment as the experimenter started to regard the elements as dead matter only reacting to external influences. During the same decade as the chemists surmounted the magicalanimistic view in favour for the empirical-causal view chemistry exploded as a science. The first generation of chemists having attained the formal operational stage developed chemistry as a true science and created masses of discoveries, breakthroughs and bulks of knowledge, changing sciences, technologies and economy. The first generation of true chemists discovered more than all generations of the whole Middle Ages together.

The same transformation took place in physics, biology, medicine, geology, geography and the human sciences. Altogether, the emergence of the formal operational stage in the minds of the scientists was the single cause to the rise of the physical sciences "im eigentlichen Sinne" (Piaget, 1975; Piaget and Inhelder, 1958; Oesterdiekhoff, 2017c; 2013a: 287-329). The formal operational stage is the cause to the explosion of scientific knowledge during the early modern times, giving the Western world the means to transform the world completely. The other parts of the world followed this transformation stepwise only during the 20th century, if at all. Piaget and Garcia (1989) himself did the most to reconstruct the development of sciences in terms of developmental psychology.

\section{Industrial Economy}

The rise of industrial economy in the Western world was not forced by economic constraints or enabled by institutional opportunities as some classic approaches assume but was the simple consequence of psychological 
stage advancements. Even at first glance this is demonstrable when considering the circumstances of the invention of the steam engine, the kernel technology of the industrial revolution. Margaret Jacob (1997) dedicated a whole monograph to show that the engine of Watt and Boulton was not a simple piece of craftsmanship, of practical knowledge only, or of simple trial and error. It resulted from the newest achievements gained in chemistry, physics, mathematics, metallurgy and engineering. Without the physics developed by Newton it wouldn't have been possible to develop this unheard masterpiece of technology (Gordon, 1988). James Watt was a scientist communicating with Priestley and Lavoisier. Therefore, the new industrial technologies came from the new sciences and the new sciences came from the newly developed formal operational stage. Thus, not only the second industrial revolution taking place at the end of the 19th century, with chemistry, pharmacy, electricity and petrol industry as leading branches, but already the first industrial revolution originated in sciences and the formal operational stage (Oesterdiekhoff, 2005; 2014a).

Of course, the formal operational stage is not only via sciences the origin of the industrial economy. People having attained advanced psychological stages are inclined to improve their abilities throughout all aspects and dimensions of their life and work, their professional and private life. People staying on preoperational stages blockade their life in consequence of their superstitions, cruel customs, irrational beliefs and insane traditions. They spent their savings to ancestors, let oracles decide their judicial cases, kill innocent persons in case of deaths because they believe every death comes from magical assassinations, tend to blood revenge, etc. They give birth to numerous children but cannot invest in their education, often not in their simple nutrition. People staying on preoperational stages cannot build up modern, industrial economies, partly in consequence of their manifold irrationalities and partly due to their lacking operational competences (Staewen, 1991; Lévy-Bruhl, 1923; 1985; Oesterdiekhoff, 2013a: 549-580; 2011: 192-205; 2014a; 2014b).

Only people staying on operational stages develop these higher forms of rationality that make industrial economy possible to appear. That is what Piagetian cross-cultural psychology involuntarily and the structural-genetic theory programme deliberately have proved. There is a clear correlation between primary and secondary socialisation, compulsory school education, psychological stage advancement, rationality in life conduct and professional abilities on the one side and economic growth, technological progress and wealth on the other side. Micro-economy and macro-economy, micro-sociology and macro-sociology have to be linked this way. Human capital theory has to be based on developmental psychology, not simply on pedagogic. People on advanced psychological stages manifest higher forms of self-discipline and peaceful behaviour, have more organizational competences and foresight, flexibility, responsibility and empathy. That is what Max Weber (1987) in his Protestant Ethics formulated, on a theoretically scanty basis and what Elias (1982) in his Civilization Theory and Alex Inkeles (1974) in his theory of Psychological Modernity described on a more elaborated basis. A true insight, however, is only reached by the consequently elaborated developmental approach.

Descriptions of entrepreneurial activities, of behaviour of clerks and workers and related computations of labour productivity in (former) developing nations completely match both to the descriptions of Weber, Elias and Inkeles and to the descriptions of the developmental approach (Staewen, 1991; Oesterdiekhoff, 2013a: 549-580; 2011: 192-205; $2014 a ; 2014 b ; 2013 b)$. Human capital formation via education and corresponding psychological stage advancements make economies grow, not simply foreign capital investments, political reforms and institutional changes. The latter ones create nothing when the former ones are missing, while the first phenomenon creates by itself capital and favourite political and societal conditions altogether.

\section{Enlightenment}

The age of Enlightenment started roughly around 1700 and had its peak during the second half of the 18th century. There must exist a systematic reason why the age of Enlightenment fell nearly in the same epoch as modern, industrial society came into being. More precisely, the age of Enlightenment came more or less some decades before the industrial epoch. Traditional history or sociology could not answer to this question, however, the structural-genetic theory programme can do that. The age of Enlightenment is simply the intellectual manifestation of the newly arisen formal operational stage in worldview, religion, politics and ethics. When developmental psychology explains history then changes of thinking and mind have to be earlier than their corresponding societal effects and economic outcomes. People must have already attained higher stages before modern, industrial societies can exist as already accomplished forms. The construction and preparatory time lasts a little. The time span between Enlightenment on the one hand and modern society and industrial economy on the other hand matches to the time span between stage advancements and their clearly visible societal and economic results. That is the reason why every nation that experienced and contributed to the age of Enlightenment also participated at the process of modernization and industrialization during the early 19 th century. 
Enlightenment consists of several elements seemingly not linked to each other when seen from a superficial vantage point. The authors belonging to the movement criticised (1) magic and superstition and to a certain extent church and religion, (2) the cruel punishment law and (3) slavery, feudalism and autocracy. They demanded a religion of reason (without legends and myths), a humane punishment law and the abolishment of serfdom in favour of liberty rights, human rights, republic, constitutional state and sometimes even democracy. Why did these authors combine the criticism of superstition and magic with the criticism of serfdom and body mutilation? Where is any coherence between these phenomena? More, did nobody in antiquity or medieval times criticise these phenomena? Further, in case such criticism was expressed in former times to a certain rate, why was then the age of Enlightenment the first time in history where such criticism became concise, penetrating and alarming?

It is a clear fact that antiquity and Middle Ages strongly supported and demanded magic, superstition, brutal punishment law, serfdom and autocracy. These phenomena existed and penetrated premodern societies because the people wanted them to exist. Therefore, they weren't criticised, or only by few and then on a scanty basis only. The age of Enlightenment came into existence because the Western humankind had attained a certain psychological stage where it could no longer accept the archaic phenomena and had stepped over a threshold where it demanded higher developed structures in worldview, customs, punishment law, ethics and politics.

Developmental psychology has evidenced that the preoperational stage is the single cause and origin to the belief in magic, witches, sorcerers, ghosts and monsters, to the strong adherence to all kinds of superstition and to the belief in mythical fantasies and incredulous legends. Every child by his seventh year roughly shares this magical-animistic and fairy tale worldview, no matter in which culture and family it is raised, simply in inevitable consequence of his or hers psychological stage structures (Werner, 1948; Piaget, 1975; Stern, 1924; Bühler and Bilz, 1977; Rosengren, 2000; Oesterdiekhoff, 2009a; 2011; 2013a).

The preoperational stage, characterizing the psychological life of the greatest part of the premodern humankind, is therefore the single cause to the same forms of superstitions, mythological fantasies and magical beliefs prevailing in the whole of ancient history (Lévy-Bruhl, 1923; 1985; Oesterdiekhoff, 2009a; 2011; 2013a; 2012; 2016c; Piaget, 1975; Signer, 2004; Werner, 1948). The premodern humankind did not deeply criticise magic and superstition because these structures were the inevitable manifestation of its psychological stage. As the European humankind - or their intellectual elites - attained the first traces of the formal operational stage, the age of Enlightenment started and the intellectuals began to criticise the archaic beliefs and practices mentioned. The age of Enlightenment, here the criticism of magic and superstition, recognizably and exclusively originated in the formal operational stage and truly in nothing else.

The same is true with the other areas of Enlightenment, the criticism of the brutal punishment law, with the criticism of serfdom and the claims for liberty rights and political reforms. Premodern peoples wanted the brutal punishment law, as modern peoples reject it. There was no cry for democracy and liberty rights in medieval times because these peoples had not developed those psychological stages that originate democracy and liberty rights. As these two phenomena will be scrutinized in the subsequent chapters, these hints may be sufficient here.

Therefore, the structural-genetic theory programme can explain the coherences between the three areas of criticism (magic, mutilation and serfdom) mentioned and between the age of Enlightenment on the one side and the origin of sciences and modern, industrial society on the other side. The origin of Enlightenment, sciences and modern, industrial society all took place during the same epoch and in the same world region. Two of these phenomena are merely intellectual in nature and these two intellectual phenomena precede the institutional-economic phenomenon. That implies, that the modern, industrial society originates in intellectual structures and in nothing else.

\section{Constitutional State and Democratic Republic}

The authors of Enlightenment, especially John Locke, Charles de Montesquieu and Jean-Jacques Rousseau, criticised forms of serfdom such as slavery and feudalism in a way unknown in all intellectual history beforehand. They showed the illegitimacy of these institutions. More, they elaborated on which principles liberty rights, republic and democracy should be based and how republic and democracy could function institutionally and practically. Thus, democracy came into being as result of planning and thinking, not as a non-intended phenomenon. Apart from the Greek forerunner, lasting during a short time span only, it happened for the first time in history that thinkers completely rejected autocracy and described principles and institutions of democracy. It is not by chance that the claim for democracy and liberty rights was announced more or less during the same period as Enlightenment, sciences and industrial economy came into existence and spread (Oesterdiekhoff, 2015; 2013a).

Historians and sociologists focus both institutional and intellectual factors as possible explanatory factors to the rise of the claim for liberty rights, republic, 
constitutional state and democracy. They sway whether the ideas of Enlightenment or the struggle for power or class conflicts be the causers to the rise of the Free World. Following the ideas of Marx they often have been tending to earmark power constellations, that is, the loss of power of the feudal elites and the rise of the bourgeoisie, as main cause to the breakdown of monarchy and autocracy in favour for rising democracy and republic (Moore, 1969).

However, constitutional state and democracy do not represent shifting power constellations, that is, the dominance of the bourgeoisie or the middle classes because they represent the whole electorate, that is, the whole nation. Democracy simply is not an instrument of a certain class to exercise power, as the institutional argumentation provides. That is the reason why the new political ideas, in the discussions before 1789, were supported especially by the noblemen, more than by the other classes and were backed by members of all social milieus. Noblemen belonged to the most enthusiastic supporters of Enlightenment and the new political consciousness. Though, the historians who emphasized the decisive role of Enlightenment to the emergence of the new political consciousness have likewise no theory available how it is explainable that the whole premodern humankind did not long for republic, constitutional state and democracy, while only the Europeans stepwise and gradually from the 18th century onwards developed this new consciousness and these new institutions.

The developmental approach has the means available to explain both the dominance of autocracy in the whole premodern world and the recent rise of the Free World (at first in the West). The preoperational stage does not know tolerance, liberty rights and democracy but emphasizes the role of authority and unchangeable laws. Only the formal operational stage both surmounts and rejects authoritarian forms and claims for democracy, liberty rights, tolerance and the rule of law (Oesterdiekhoff, 2015; 2014c).

Developmental psychology conducted experiments among children to test their political consciousness. Younger children understand rules, even game rules, as eternal, unchangeable and set by parents, elderly, or god. They believe that they have to obey to the eternal customs. Adolescents, raised in modern societies, surmount these beliefs and introduce democratic procedures as those to decide over the legitimacy of rules (Piaget, 1932). Correspondingly, younger children have little tolerance with deviating opinions, emphasizing the dominance of the group upon the individual, thus tending to isolate or to expel deviants or individualists. They prefer a collective mind; all members should share the same opinions and stances (Gallatin and Adelson, 1970; Rosenberg, 1988).
Though children understand rules as holy and eternal they are bad in knowing and applying them. Their comparably scanty usage and incompetent praxis is not present in their consciousness and reflectivity, of course. Thus, they combine a holy ideology with a poor praxis, relying on that what authorities, parents and elderly tell them. Without their assistance, they would lead a rude collective life as William Golding had described in Lord of the flies. Conversely, modern adolescents both believe in the democratic changeability of laws and rules and are better in their understanding and application. Thus, they combine a democratic consciousness (of legislation) with a cultivated social praxis (competent rule application) (Piaget, 1932).

Piagetian cross-cultural psychology applied these tests both to children and adults of premodern societies. It was found that premodern adults preserve the political consciousness of children, that is, they maintain the belief that rules and laws are unchangeable, are set by ancestors and divinities and are not exposed to the will of any people. In case they actually change any rules then with the consciousness to restore them and not to break the old and holy rules. Accordingly, cross-cultural psychology can evidence that premodern peoples do not develop democratic forms of political consciousness but are in favour of authoritarianism (Havighurst and Neugarten, 1955: 125-142; Radding, 1985: 74-108; Oesterdiekhoff, 2009a: 261-284; 336-444; 2013a: 391-493).

Historians have described that medieval peoples regard laws as holy and unchangeable, as superior to any will of people and as set by god, kings and ancestors (Kern, 1952; Radding, 1985). Premodern peoples all over the world have regarded their customary laws just this way, as Islamic peoples do conceive the Sharia by now. Therefore, they are in favour of authoritarian forms of government, strictly rejecting liberty rights and democracy. Greater parts of Europeans even during the 19th and early 20th century still rejected democracy. Democracy and constitutional state developed in Europe stepwise throughout the 19th century, gaining an overweight only after 1945 or even after 1975, when the dictatorships on the Iberian peninsula collapsed. Surveys have shown that greater parts or even majorities in the developing nations reject democracy even by now. Often electorates choose in free elections parties and leaders who proclaim to abolish democracy after election, or who announce that they want to continue their already existing dictatorship. Thus, autocracies in developing nations exist not really against the will of the people. There is no regime that can prevail without legitimacy and support of the nation. Therefore, autocracies are wished by the people. The worldwide slow march to democracy over the past 100 years is nothing less than the reflection or manifestation of the likewise slow worldwide psychological stage development (Oesterdiekhoff, 2015; 2009a: 261-284; 336-444; 2013a: 391-493). 
As children do, premodern peoples combine a holy law understanding with a scanty social and political praxis. Corruption, clan criminality, mafia, high violence rates, violence against women and children, duel culture, bloodshed, etc., prevail in every kind of premodern society. Premodern people do not lead a life in a secure civil society where the citizens feel responsible for the maintenance of rule. They do not live in a constitutional state where liberty rights are preserved and where freedom of press, freedom of confession and rights of minorities are guaranteed. Political power is exercised by private persons and public functions exist on a scanty basis only. Accordingly, the social and political conditions in the developing nations reveal comparably greater forms of insecurity, violence, criminality and lack or weakness of the rule of law. As democracy develops only stepwise in the developing world, so does constitutional state, civil society and socio-moral life (Oesterdiekhoff, 2016d; 2017b; 2015).

Civil society and constitutional state are yet preconditions to democracy. Only when people are capable to maintain social order, care for society, develop tolerance with different opinions and feel responsible for state, law and nation are they able to erect democracy and a free society. This improvement of civil life, security and moral life has taken place in modern societies over the past centuries in a clearly measurable rate. Thus, the most advanced nations combine a democratic mind with improved socio-moral praxis, as the modern adolescents do, measured by the Piagetian surveys. Thus, as long as humans stay on the preoperational stage they have difficulties to carry civil society and constitutional state. People on formal operational stages, however, are able to improve constitutional state, civil society and the socio-moral life (Oesterdiekhoff, 2015; 2013a: 391-493).

\section{The Humanitarian Revolution}

The authors of Enlightenment criticised barbarian social institutions and moral practices such as slavery, feudalism, cruel punishment law, duel culture and violence against women, children and animals. Piagetian cross-cultural psychology conducted empirical surveys concerning moral attitudes, finding that premodern peoples do not surmount Kohlbergian moral stages one and two, with only a few people reaching stage three. Stages one and two refer to developmental ages of children by their tenth year. Modern peoples yet distribute on the stages three, four and five with four as the modal stage. This confirms the fact that modern peoples develop five to ten years more than premodern ones (Kohlberg et al., 1978; 1980; Edwards, 1975; Oesterdiekhoff, 2009a: 404-409; 2013a: 495-522; 2011: 162-175).
The lower socio-moral consciousness of the premodern humankind induced the people to perform and to accept cruel, insane and dismal social customs such as slavery, duel culture and body mutilation in punishment law. The authors of Enlightenment were the first to attain the moral stages four and five, thus attaining higher stages of empathy, perspective-taking, responsibility, shame, guilt feelings and socio-moral life altogether. From those sources whole modern nations attained the modal stage four during the 20th century. Modern people completely reject slavery, duels and brutal punishment law. What happens when migrants staying on the stages one and two have the opportunity to live out their primitive mentality and their attitudes regarding women and thankful response to hospitality could be seen at New Year's eve 2015 in Cologne (Oesterdiekhoff, 2016e). That this incident is only the clearly visible iceberg of the problems these people make show statistics concerning their criminality, education, occupation, political attitudes and religious commitment (Sarrazin, 2018).

The whole premodern humankind, including nature peoples, ancient and medieval civilizations all around the world, practised more or less the same forms of punishment. Torture and body mutilation such as crucifixion, burning, cutting to pieces, beheading or spearing to death, or boiling in hot water in front of bulks of folk were common punishments for theft, treachery, forging or whatever. The European enlightenment was the first movement in world history to abolish these practices and to replace it by forms of punishment that spared the human body. The humanisation of punishment law followed the psychological stage development of the Europeans during the past centuries. The entire world copied more or less the European reforms with some time distance in consequence of likewise subsequent psychological advancements (Pinker, 2011; Oesterdiekhoff, 2009a; 2011: 162-175; 2013a: 495-522; 2014c; 2016d; 2017b).

Accordingly, developmental psychology described that small children do not only perform more physical violence than older ones but also that young children strongly claim and support severe punishments. Only children after their $10^{\text {th }}$ year tend to support more appropriate and reasonable punishments (Piaget, 1932; Stern, 1924).

Physical violence is omnipresent in premodern societies. Violence against women, children and dogs or cattle manifests extreme forms, in comparison with the today's most advanced nations. Bloodshed, vengeance and duels were seen as holy duties, devastating whole regions and affecting population growth. Empirical surveys in present-day developing nations show that these peoples support and perform much more than people of the most advanced nations violence against women and animals and accept much more physical violence for reasons of honour or whatever. Accordingly, 
homicides are much more frequent in developing nations and are among premodern societies yet more present than in the todays developing nations. The currently most advanced nations know only a small bit of that violence Europe had to suffer in the 18th and 19th century. Violence has continuously declined over centuries. Violence against children for educational reasons were common in Europe by 1965 roughly and declined afterwards considerably and continuously. Europe in the first half of the 19th century enacted the first laws against the maltreatment of animals. Protection of wildlife and cattle, unknown in developing nations around the middle of the 20th century or partially even by now, has got some strength over the past decades (Pinker, 2011; Oesterdiekhoff, 2011: 162-175; 2013a: 495522; 2016d; 2017b).

The Arena games of the Roman Empire are the best examples of the lower socio-moral stage of the whole premodern humankind. They consisted of mortal duels (gladiator fights), capital punishment of great numbers of delinquents and animals who fought against each other or against humans. These three elements existed throughout the whole premodern world, including Europe by the age of Enlightenment. The games belonged to the greatest amusements the Romans had and weren't truly criticized or rejected. They simply existed because the people wanted them to and enjoyed them. They don't exist anymore, neither in its compactRoman-form nor as single elements, because modern peoples could neither enjoy nor sustain them. Divergent psychological stages are the sole cause to their former existence and their present-day disappearance (Oesterdiekhoff, 2009b; 2011: 173-175; 2013a: 519-522).

Accordingly, premodern peoples have no problems with slavery and related forms of dependency and serfdom. Slavery was common among nature peoples such as the native Americans from south and north, among nature peoples in Polynesia and Africa and among every Asian civilisation by the 19th century at least. Slavery usually implied the full right upon life and death of the slave, including sexual usage and killing for any reasons without any legal hindrances to that. It is obvious that slavery was only possible because premodern peoples stood on preoperational stages and did not surmount moral stages one and two. Only people with low levels of socio-moral consciousness are ready to perform and to accept slavery. Europe, China, and Japan are said to have abolished slavery during the early modern times. Authors of Enlightenment had prepared the movement, the French Revolution of 1789 freed the slaves in the colonies, the British navy prohibited Atlantic slave trade since the 1830ies, the Europeans stopped the Arabian slave states at that time and by 1850 all European nations had forbidden any form of slavery forever (Oesterdiekhoff, 2013a: 395-397; 2017b).

\section{Explosion in Painting}

Ancient Egyptian painting manifests another style as ancient or medieval Chinese or Indian painting. Yet, ancient or medieval Mediterranean and ancient or medieval Oriental painting exhibit common features underlying their different styles. These common features were only surmounted by the European painting starting during Renaissance and further European advancements unfolding in the early modern era.

Some historians of art, especially before 1940 but also in recent times, have described similarities between children's drawings and the pre-Renaissance painting in its worldwide dimensions (Gablik, 1976; Schäfer, 1986; Oesterdiekhoff, forthcoming a). Preoperational spatial understanding is the cause to these common features. The preoperational space understanding only knows topological relations, while the concrete operational space understanding manifests Euclidean and projective space relations, coming into existence in the history of painting only during the European Renaissance. It was found that the worldwide pre-Renaissance painting corresponds to the third stage of children's drawings the intellectual stage - according to Luquet (1927), while the fourth stage - the visual stage-corresponds to the Renaissance painting and the subsequent European arts. Modern children reach the concrete operational space understanding and the visual stage with 9 years roughly.

The common features of the pre-Renaissance art, originating in the topological or preoperational stage, are definable the following way. The painters show no space but locales only. The pictures are two-dimensionally only, incapable of presenting three-dimensional depth. Objects are presented flat and not bodily, missing any foreshortenings, oblique views and diminutions. Measurements, distances and proportions are not seriously considered. Emotionally important objects are painted bigger than secondary phenomena. Perspectives are missing. Far-distant and nearby objects are painted with the same sizes. The painters paint against their knowledge of the objects (intellectual realism) and not against what is given to the eyes (visual realism). That is, their paintings do not come close to photos and are bad in coping reality. They paint objects schematically. There was no ancient or medieval painter who was able to paint a human body (or whatever) as it looks like in reality. For example, ancient Egyptians, over 3.000 years, always paint humans this flat or non-bodily way: Breast, shoulders and eyes were painted in front view, while the face, the hip, the buttocks, the legs and the feet in profile. The painters paint alike that what is viewable and that what is not viewable but belongs to the object anyway, a phenomenon called x-ray painting. Ancient and medieval painters never paint light and shadows. "I have happened on no evidence to show that any [ancient] 
Greek ever sat down and drew a view, or a group of figures, or a congeries of objects, such as his tables and chairs, as they appeared relatively to each other in their respective shapes, sizes and positions, as seen from a single point of view." (Ivins, 1964: 31)

Painting experienced an unheard breakthrough during Renaissance and subsequent centuries, a breakthrough limited to European culture by 1900 roughly. The invention of the central perspective with its foreshortenings, diminutions and oblique views is only one element of this revolution. Piaget has shown in two ample volumes that the central perspective comes into existence as consequence of the concrete operations, that is, as consequence of the replacement of the topological by the Euclidean and projective spaces. People on the concrete operational stage discover the space in painting and are able to consider depth, proportions and distances. They have the preconditions to paint persons and objects voluminously and bodily. They avoid all the failures of intellectual realism in favour for visual realism. As they paint realities as they paint light, colour shades and shadows for the first time in history. European painters cared for the reproduction of every single detail ancient and Oriental painters simply overlooked. European artists learned to come close with their paintings to photos and full reality (Gablik, 1976; Schäfer, 1986; Oesterdiekhoff et al., 2019).

There was not one pre-Renaissance painter in the whole world being able to paint a picture of the quality Das große Rasenstück of Dürer (1502) manifests. There was not one ancient, medieval or Oriental painter who was enabled to paint a portrait of the perfection Pieter van den Broecke by Franz Hals (1633) or Pope Paul III. by Tizian (1546) exhibit. Not one pre-Renaissance artist could have reached the excellence Albert Anker attained with Children at breakfast in 1879. Not by chance is Leonardo's Mona Lisa the most famous picture today.

Altogether, psychological stage development has carried the whole history of painting. Not conventions or styles but psychological maturation built the main trajectory in the history of arts. European culture from the Renaissance onwards by 1900 or 1950 attained higher stages in painting unparalleled in the whole history that apparently reflect psychological stage advancements.

\section{Literature}

Narration historically starts with creation and telling of myths. From the Stone Ages to the end of the premodern world the myth was the most used form of narration all over the world. The myth is the single form of narration among illiterate nature peoples, the most frequent form of narration among the illiterate people in the famous Eurasian agrarian civilizations by the 19th century and attracted greatest interest among noblemen in the palaces of India, Ottoman Empire, Persia and China still during the early modern times. The myth is the origin of literature and religious legends and the precursor of philosophy and science.

Premodern people commonly do not discriminate myths from reportages or records. They usually do not regard myths as simply fictional but believe they tell true incidents. They use myths for explaining nature and reality, different from that what modern fictional literature does. Against modern understandings, myths commonly describe physical impossibilities and incredulous events. Ancient people yet thought otherwise. Myriads of mythologists worked out that initially there weren't any divergences between myths for children and those for adults. Only in more recent times, some divergences have occurred. Myths, today told to children only, once entertained the whole family and village community. Children and archaic adults create the same myths and have the same attitude to them (Wundt, 1914: 33-37; Bühler and Bilz, 1977; Rosengren, 2000; Stern, 1924; Oesterdiekhoff, 2016f).

Epic, tragedy, comedy and drama manifest more elaborated forms of narration. The classic antiquity created these forms of narration that vanished again after the collapse of the Roman Empire. According to LePan, only during the 1590ies, with Marlowe and Shakespeare, narration reached again the level the classic authors had already attained 1.300 or 2.000 years ago. LePan (1989) dedicated a whole monograph to interpret the English literary history in terms of developmental psychology. $\mathrm{He}$ described that the medieval English (European) literature only knew simple plots manifesting features typical for children. "Thus almost all works of literature in primitive societies are plotted in single sequences rather than dobble-plotted' with two or more related threads of story inter-woven." (LePan, 1989: 178) The simple plot did not well describe motives if at all, did not characterize psychological features, did not combine cause and effect and therefore did not arouse expectations. The audience focused single incidents as do children today when watching TV (Oesterdiekhoff and Rindermann, forthcoming).

The complex plot, coming into existence with Shakespeare in England, already manifests those features all kinds of drama have since. LePan shows that psychological stage advancements must have taken place both in authors and audience to make this explosion in literary possible.

However, a new kind of literature appeared that exerted more influence than the drama had done. Though a handful or a dozen of novels had been already written in antiquity, the novel started to disseminate from the 16th century onwards. El criticón, Simplicissimus Teutsch, Eulenspiegel and Don Quichote belonged to the first true novels in modern literary history. The next step was given by the developmental novel, exemplified by 
Robinson Crusoe, The history of Tom Jones and Geschichte des Fräulein von Sternheim. The European novel exploded during the 19th century and later on with Austen, Dickens, Dostojewski, Tolstoi, Mann, Proust, etc., shaping the consciousness and education of whole nations. More than any other form of narration the novel is capable to tell complex stories and to reflect the full density and complexity of real life. More than any other form the novel can dive into psychological structures and social conditions. The persons described have greater roundness and depth and the ideas outlined are more profound. The novel alone can show the full reality (Oesterdiekhoff, 2013a: 346-349, Oesterdiekhoff and Rindermann, forthcoming).

On the whole, literary history manifests the same process of psychological maturation as painting does. From myth over drama and tragedy to novel there is recognizable a clear tendency to greater complexity and mental depth. The breakthrough of literature took place during the same period as modern society came into being. Modern literature has been part and manifestation of the European miracle over some centuries. Of course, nowadays, both modern society and literary excellence have more or less disseminated worldwide.

\section{Music}

To my knowledge, the history of music is not written in terms of psychological stages by now. Thus, there is some difference to the history of painting and literature concerning scientific endeavours related. However, presumably all elements needed to that task have been available for long. Multi-voiced music is central to the development of Western music. It originated in the link of notation and composition. The great breakthrough in the entire music history of the world came with the 12 steps tone system around 1700. It enabled to compose in all kinds of major and minor. Johann Sebastian Bach is the main protagonist of this greatest revolution in music history. Composers like Georg Friedrich Händel, Ludwig van Beethoven, Franz Schubert, Joseph Haydn, Wolfgang Amadeus Mozart, Felix MendelssohnBartholdy, Giuseppi Verdi, Richard Wagner, Fryderik Chopin, Clara and Robert Schumann, Johannes Brahms, Claude Debussy, Pjotr Tschaikowsky and others created the great compositions of classic music.

This greatest revolution in the music history of the world took mainly place from 1700 to 1900 in Europe, during the same time as the novel conquered literature and the painting fully matched reality, as the Western world went through the greatest transformation in world history and as the Europeans subsequently attained the formal operational stage and reached psychological developmental ages unparalleled in history. The great concert halls in Tokio, Moscow, Sydney, New York,
Singapore, Johannesburg, Kuala Lumpur or Hamburg almost always only perform these classic composers mentioned. They do not play European composers of the 15 th century or Asian composers of premodern times for obvious reasons. Premodern music from whichever world region or from whichever styles simply cannot match classic music.

It is clear that psychological stage advancement is the cause to this explosion of composition. Psychological stage development likewise caused the breakthroughs in music, literature and painting having taken place in Europe during the past centuries. The structural-genetic theory programme is the fundamental theory to the history of the fine arts and has found the key to explain their main trajectories.

Modern society and corresponding psychological stages might have been the prerequisites to subsequent music revolutions. The diverse forms of Pop music after 1960 and Latin music may be part of this process. Both reveal an explosion of talent and excellent compositions with thousands of earwigs that probably have no matching parallels in the various forms of premodern music (Oesterdiekhoff, 2013a: 357-361).

\section{European Expansion}

Sea voyages across oceans and intercontinental traffic exist since prehistory. There is abundant and clear evidence that copper and tin was exported from both Americas to the Mediterranean since the early Bronze Age over several thousand years on a more or less regular basis. People from Asia and Europe met in America and Africa. China, India, Europe and the Mediterranean were connected to the mines of Africa some thousands of years ago. The cultures of the world were much more interconnected to each other and influenced more each other than school books usually reveal as research has shown over the past generations (Bailey, 1994; Fell, 1977; Thompson, 1992).

However, the more recent European expansion yet soon exceeded the ancient intercontinental contacts. The Portuguese and the Spaniards conquered Latin America and imprinted influences existing and dominating by now, concerning not only language and religion. They connected Latin America to the since then never broken again chain of global developments, enabling Latin America to participate at the transformation to modern, industrial society. Of course, as the 16th century Iberians had been more brutal than the 19th century Europeans their colonisation had much more dismal aspects than the $19^{\text {th }}$ century colonisation and imperialism. People of many European nations occupied North America later on, also leading the Amerindians close to distinction and transforming that region to the top of the industrial world. On the whole, North and South America became 
the greatest colony for the Europeans to settle. Initially the double continent was a European satellite, later on it became independent. The double continent and Europe form the kernel of the Western world by now.

Great Britain became the greatest imperialistic power in world history, ruling roughly a quarter of the world's surface around 1914. There weren't many nations in the world this aggressive military state did not invade or led a war with. Apart of America, British colonizers conquered South Africa, New Zealand and Australia. More, the Britons ruled whole India by 1947 and greater parts of Africa by 1960. Further, the Europeans ruled Africa, Polynesia and South East Asia by 1945 or by 1960, respectively (Ferguson, 2011; Chaudhuri, 1978).

The geography of Russia is a sometimes overlooked part of the European expansion. The origins both of Russia and Ukraine are European in nature. The first Russian city, Novgorod, belonging to the Hanse association, was founded by Germanic Vikings, as northerners built the origin of Ukraine. The Kremlin, partially built by Italian architects, symbolizes the European influences, strengthened by Peter the Great who learned in the Netherlands and built the maritime door to Europe, St. Petersburg. Russia participated at the transformations of Europe to a certain extent during the early modern times. Of course, she was not a forerunner but more a copying backbencher with dubious successes. Though, its vast expansion between 1500 and 1900 has to be explained against the background of this participation. It is possible to compare the conquest of North Asia by the Russians with the conquest of Australia and both Americas by the Europeans. As the Russians imprinted modern civilization to North Asia, as the Europeans did concerning both Americas.

Thus, Europeans between 1500 and 1900 occupied and colonized both Americas, North Asia, Greenland, Australia and New Zealand. By now these parts of the world have remained European settlements and nations, amounting more than half of the globe's surface. The decolonization after 1960 in the South did not abolish these occupations mentioned.

The Europeans discovered any small region in the world and contacted almost all cultures existing in the period. They described any small people in the world at length and analyzed their customs, religion, mind and their way of life altogether. They methodically scrutinized the botany and fauna, the geology and geography of the regions they travelled through. Thousands over thousands of ethnographic descriptions related are stored in libraries - an achievement unheard in all history. Europeans made dictionaries of thousands of languages and researched their features. No other civilization has ever accomplished comparable achievements.

The moral and political problems of the era of colonialism and imperialism have been widely discussed.
Exploitation, alienation, incapacitation and destruction of cultures belong to the many sins Europeans committed at that time. However, this era imported the modern, industrial society to the non-Western world. Nothing could be more wrong than the statement of Chancellor Merkel, Europe had blockaded Africa's development for over 400 years. Conversely, Europe delivered all the mental, informational, cultural, technological, educational, scientific, medical and economic impulses to the non-Western world that were needed to copy the Western process of modernization and industrialization. Only this way became the modern, industrial society more or less dominant right across the whole globe (Oesterdiekhoff, 2005).

The globalization process does not only concern economic and institutional aspects but also psychological structures. Greatest parts of the preoperational mind and worldview (Lévy-Bruhl, 1923; 1985), dominating the non-Western world a few generations ago, have largely disappeared now. Psychological stage advancements have taken place more or less on a global scale. Of course, there are still developmental gaps between peoples of the most advanced nations and those of the developing world. Though, the gaps are closing. Yesterday's backbencher can be the frontrunner of tomorrow. Just this shift of powers and capabilities is already happening right now (Oesterdiekhoff, 2016d; Frank and Gills, 1993; Landes, 1998; Maddison, 2001).

Obviously, psychological stage advancements in the Europeans are connected to their cultural advantages that made their expansion possible. It helps to explain how some thousand Britons could rule India, or how small groups could crash the Aztec and Inca civilisation. It helps to explain how the intentions to explore and to discover arose and how the contacts between the foreign invaders and the local residents developed in favour for the first group. Todorow once wrote that it was their literacy that enabled the Europeans to smash the Amerindians in North America. Yet literacy was only a small part of the cultural inequalities but deeply connected to stage differences as Piagetian psychology had described at length (Luria, 1982; Mogdil and Mogdil, 1976). Piagetian psychology is also requested regarding the explanation to the stage differences between former and present-day Westerners, that is, why former Europeans often tended to maltreat the peoples they encountered and why they now disapprove their antecedents, of course, often with wrong argumentation (consider Merkel's statement). Piagetian psychology is also helpful to discriminate between those who are able to discuss the achievements and failures of the colonization properly on the one side and those who have only some moral sentiments but neither knowledge nor judgment about that on the other side. 


\section{Conclusion}

The European miracle must be discriminated from former breakthroughs somewhat. Never before was a transformation thus penetrating and ground-breaking, including the Neolithic revolution and the rise of state and civilization. Not one transformation before had aroused such tremendous effects. More, never before whole nations had attained the formal operational stage. In ancient times only some small elites might have touched this stage. Modern nations are yet separated from the whole premodern humankind by 5, 10 and even more developmental years. Therefore, the emergence of the modern, industrial society is a radically new phenomenon. Even huge transformations in former times happened all within the preoperational or concrete operational stage. Advancements in China around 1300 or in India around 200, in Rome around Caesar's time or in Arabia around 1000 - they all happened within the lower psychological stages.

Of course, the European miracle is somehow history because now all nations are on the stage or at its edge at least. China, India, Indonesia or Brazil are on the jump, in 100 years perhaps three billions of Africans will look on perhaps 500 millions of Europeans. More, even the European miracle once resulted from global influences. Further, almost every world region was once frontrunner, while others, later great, were at times backbenchers. The worldwide influences have dominated and steered every nation more or less to similar directions, mostly balancing momentary inequalities quickly. Advantages given to one culture were thus mostly only of momentary character. However, when Arabia was frontrunner around 1000 A. C. and Greece around 400 B. C. - they were so in a different way from the European preponderance after 1700. Neither was their advancement related to the backbenchers so big as was the gap between Europe and the non-Western world around 1900, nor did the then given gap implied such huge psychological stage differences.

Modern, industrial society consists of transformations in sciences, industrial economy, political structures (such as democracy, civil society and constitutional state), Enlightenment (such as disenchantment and claim for liberty rights), humanitarian revolution (such as diligent childcare, animal protection, abolishment of slavery, serfdom and brutal punishment law and decline of violence and criminality) and revolutions in music, painting and literature. Every single transformation simply manifests psychological stage advancements. More exactly, every kind of modernization, every transformation of a certain dimension of culture during modernization, is either a manifestation of psychological stage development or a side effect of this. Whenever a nation attains the formal operational stage it cannot avoid developing stepwise modern society. Small milieus with people on the formal operational stage cannot alone create modern society (Hellenistic science revolution as example to this). When greater parts yet join the transformation then the emergence of modern, industrial society becomes inevitable (Oesterdiekhoff, 2007; 2014a; 2014b; 2014d; 2014e).

Conversely, whenever people stay on preoperational stages then they do not develop sciences, industrial economy, democracy, constitutional state, humanitarian revolution, visual realism in painting, classic music and great literature à la Proust or Mann. Preoperational peoples know or manifest magic, superstitious religion (ancestor worship and nature religion), simple technologies, hunting, fishing, farming, craftsmanship, trading, autocracy, slavery and the fine arts in their archaic forms (Oesterdiekhoff, 2011; 2013a; 2016a; 2016b; Lévy-Bruhl, 1923; 1985).

The structural-genetic theory programme collapses classical and current sociology and economy with their belief in institutions, social conditions, materialistic circumstances and capital. It rather shows that presumed objective and materialistic phenomena are mainly results and consequences of psychological stage developments (Oesterdiekhoff, 2016b; 2018). The structural-genetic theory programme is the first theory that succeeds in revealing the true foundations of the history of language, sciences, economy, law, politics, morals, religion and fine arts. These foundations are psychological stage structures. Premodern cultural manifestations originate in preoperational stages and modern manifestations of culture root in the formal operational stage. The discovery of the childlike nature of premodern humans and of the stage advancements of modern humans, is the greatest discovery ever made in the human and social sciences (Oesterdiekhoff, 2016a; 2016c).

On the whole, the structural-genetic theory programme has found the key both to understand the origin and the nature of modern, industrial society. The new theory is superior to the classic approaches of Durkheim, Weber, Parsons and Elias and has much more explanatory power and empirical evidence than current approaches contributed by Jones (1987), Ferguson (2011), Macfarlane (2000), Landes (1998), Pomeranz (2001), Sanderson (1999) and Wallerstein (1974).

\section{Author's Contributions}

Jörn Rüsen: Helped in developing ideas and conceptions, wrote the last chapter and read the paper.

Hans-Jürgen Hummell: Helped in developing the conception, discussed the problems and read the article for corrections.

Georg Oesterdiekhoff: Wrote the first parts of the article, developed the research idea, and read the article for corrections. 


\section{Ethics}

The authors confirm that the content does not violate any dignity of certain ethnic groups or minorities.

\section{References}

Ashton, P.T., 1975. Cross-cultural Piagetian research: An experimental perspective. Harvard Educ. Rev., 45: 475-506. DOI: 10.17763/haer.45.4.kpq1578t13tk0541

Bailey, J., 1994. Sailing to Paradise: The Discovery of the Americas 7.000 B. C. 1st Edn., Simon and Schuster, ISBN-10: 0684812975, pp: 463.

Bühler, C. and J. Bilz, 1977. Das Märchen und die Phantasie des Kindes. 1st Edn., Springer Verlag, Berlin, ISBN-13: 978-3-540-08221-7.

Chaudhuri, K.N., 1978. The trading world of Asia and the English East India Company 1660-1760. Cambridge University Press, London.

Dasen, P. and J.W. Berry, 1974. Culture and Cognition. Readings in Cross-Cultural Psychology. 1st Edn., Methuen and Co, London.

Dasen, P., 1977. Piagetian Cross-Cultural Psychology. 1st Edn., Gardner Press, New York, ISBN-10: 0470151862, pp: 379.

Diamond, J., 1998. Guns, Germs and Steel: A Short History of Everybody for the Last 13.000 Years. 1st Edn., Vintage, New York, ISBN-10: 0099302780, pp: 480.

Edwards, C.P., 1975. Societal complexity and moral development. Ethos, 3: 505-527.

DOI: $10.1525 /$ eth.1975.3.4.02a00030

Elias, N., 1982. Power and Civility. 1st Edn., Pantheon, New York, ISBN-10: 0394527690, pp: 376.

Fell, B., 1977. America B.C.: Ancient Settlers in the New World. 1st Edn., Demeter Press, New York, ISBN-10: 0812906241, pp: 312.

Ferguson, N., 2011. Civilization: The West and the Rest. 1 st Edn., Penguin Books, London, ISBN-10: 1846142822, pp: 432.

Frank, A.G. and B.K. Gills, 1993. ReOrient: Global Economy in the Asian Age. 1st Edn., University of California Press, ISBN-10: 0520211294, pp: 416.

Gablik, S., 1976. Progress in Art. 1st Edn., Thames and Hudson, London, ISBN-10: 0847800822, pp: 192.

Gallatin, J. and J. Adelson, 1970. Individual rights and the public good: A cross-national study of adolescence. Comparat. Polit. Stud., 2: 226-244. DOI: $10.1177 / 001041407000300205$

Gordon, R.B., 1988. Who turned the mechanical ideal into mechanical reality? Technol. Cult., 29: 744-778. DOI: $10.2307 / 3105044$

Habermas, J., 1989. On Historical Materialism. 1st Edn., University Press, Indiana.

Havighurst, R. and B. Neugarten, 1955. American Indian and White Children: A Sociopsychological Investigation. 1st Edn., University Press, Chicago. pp: 335 .
Ibarra, L., 1994. Las dificultades de Jean Piaget para vincular el desarrollo ontogenético y filogenético del conocimiento. Iztapalapa, 35: 77-88.

Ibarra, L., 2007. Creencias, mitos y rituales en el mundo prehispánico. Una explicación desde la teoría históricogenética. Universidad de Guadalajara, Guadalajara.

Inkeles, A., 1974. Becoming Modern: Individual Change in Six Developing Countries. 1st Edn., Harvard University Press, pp: 437.

Ivins, W., 1964. Art and Geometry: A Study in Space Intuitions. 1st Edn., Dover Publications, pp: 113.

Jacob, M.C., 1997. Scientific Culture and the Making of the Industrial West. 1st Edn., Oxford University Press, ISBN-10: 0195082192, pp: 269.

Jones, E., 1987. The European Miracle: Environments, Economies and Geopolitics in the History of Europe and Asia. 1st Edn., Cambridge University Press, London, ISBN-10: 0521336708, pp: 279.

Kern, F., 1952. Recht und Verfassung im Mittelalter. Wissenschaftliche Buchgesellschaft, Darmstadt.

Kohlberg, L., E. Turiel and C. Edwards, 1978. Moral development in Turkish children, adolescents and young adults. J. Cross-Cultural Psychol.

Kohlberg, L., M. Bar-Yam and A. Naame, 1980. Moral reasoning of students in different cultural, social and educational settings. Am. J. Educ., 88: 345-352. DOI: $10.1086 / 443530$

Landes, D.S., 1969. The Unbound Prometheus: Technological Change and Industrial Development in Western Europe from 1750 to the Present. 1st Edn., Cambridge University Press, London, ISBN-10: 0521094186, pp: 576.

Landes, D.S., 1998. The Wealth and Poverty of Nations: Why Some are so Rich and Some so Poor. 1st Edn., W.W. Norton and Company, New York, ISBN-10: 0316908673, pp: 650.

LePan, D., 1989. The Cognitive Revolution in Western Culture: The Birth of Expectation. 1st Edn., Macmillan Press, London, ISBN-10: 033345796X, pp: 370.

Lerner, D., 1958. The Passing of Traditional Society Modernizing the Middle East. 1st Edn., Ill, Glencoe.

Lévy-Bruhl, L., 1923. Primitive Mentality. 1st Edn., The Macmillan Press, New York.

Lévy-Bruhl, L., 1985. How Natives Think. 1st Edn., University Press, Princeton.

Luquet, G.H., 1927. Le dessin enfantin. Paris.

Luria, A.R., 1982. Cognitive Development: Its Cultural and Social Foundations. 1st Edn., Harvard University Press, Boston, ISBN-10: 0674137329, pp: 175.

Macfarlane, A., 2000. The Riddle of the Modern World: Of Liberty, Wealth and Equality. 1st Edn., Palgrave Macmillan, ISBN-10: 0312232047, 326.

Maddison, A., 2001. The World Economy: A Millennial Perspective. 1st Edn., Development Centre of the Organisation for Economic Co-operation and Development, ISBN-10: 9264186085 , pp: 383. 
Mogdil, S. and C. Mogdil, 1976. Piagetian Research: Compilation and Commentary. 1st Edn., NFER, ISBN-10: 0856331031, pp: 331.

Mokyr, J., 1990. The Lever of Riches: Technological Creativity and Economic Progress. 1st Edn., Oxford University Press, London, ISBN-10: 019987946X, pp: 368 .

Moore, B., 1969. Social Origins of Democracy and Dictatorship: Lord and Peasant in the Making of the Modern World. 1st Edn., Penguin Books, London, New York.

North, D. and R. Thomas, 1973. The Rise of the Western World: A New Economic History. 1st Edn., University Press, Cambridge, ISBN-10: 1107469430, pp: 179.

North, D.C., 1990. Institutions, Institutional Change and Economic Performance. 1st Edn., Cambridge University Press, London, ISBN-10: 0521397340, pp: 152.

Oesterdiekhoff, G.W., H.J. Hummell and G. Dux, 2019. The development of painting in history, Psychological stages and sequential epochs. Int. J. Anthropol., 34: 157-180.

Oesterdiekhoff, G.W and H. Rindermann (forthcoming). Advancements in the history of literature: Psychological stages and sequential epochs.

Oesterdiekhoff, G.W., 2005. Entwicklung der Weltgesellschaft: Von der Steinzeit zur Moderne. 1st Edn., Lit-Verlag, Hamburg and Münster, ISBN-10: 3825889602, pp: 382.

Oesterdiekhoff, G.W., 2007. Die Entstehung der Industriemoderne in Europa. Der strukturgenetische Erklärungsansatz. Sozialwissenschaftliches J., 2: 9-35.

Oesterdiekhoff, G.W., 2009a. Mental Growth of Humankind in History. Bod, Norderstedt, ISBN-10: 3837093182, pp: 456.

Oesterdiekhoff, G.W., 2009b. The arena games in the Roman empire: A contribution to the explanation of the history of morals and humanity. Croatian J. Ethnol., 46: 177-202.

Oesterdiekhoff, G.W., 2011. The Steps of Man Towards Civilization: The Key to Disclose the Riddle of History. 1st Edn., Bod, Norderstedt, ISBN-10: 3842342888, pp: 238.

Oesterdiekhoff, G.W., 2012. Was pre-modern man a child? The quintessence of the psychometric and developmental approaches. Intell. Multi. J., 40: 470-478. DOI: 10.1016/j.intell.2012.05.005

Oesterdiekhoff, G.W., 2013a. Die Entwicklung der Menschheit von der Kindheitsphase zur Erwachsenenreife. 1st Edn., Springer VS, Wiesbaden, ISBN-10: 3531197274, pp: 626.

Oesterdiekhoff, G.W., 2013b. Unternehmerisches Handeln und Gesellschaftliche Entwicklung. 1st Edn., Springer VS, Wiesbaden, ISBN-10: 3663117022, pp: 360.
Oesterdiekhoff, G.W., 2014a. The rise of modern, industrial society: The cognitive-developmental approach as key to disclose the most fascinating riddle in history. Mankind Quarterly, 54: 262-312.

Oesterdiekhoff, G.W., 2014b. Can childlike humans build up and maintain a modern, industrial society? Mankind Quarterly, 54: 371-385.

Oesterdiekhoff, G.W., 2014c. Evolution of law and justice from ancient to modern times. J. Eur. History Law, 5: 54-64.

Oesterdiekhoff, G.W., 2014d. Psychological stage development and societal evolution: A completely new foundation to the interrelationship between psychology and sociology. Cult. Int. J. Philoso. Cult. Axiol., 11: 165-192.

DOI: $10.5840 /$ cultura201411110

Oesterdiekhoff, G.W., 2014e. The role of developmental psychology to understanding history, culture and social change. J. Soc. Sci., 10: 185-195.

DOI: $10.3844 /$ jssp.2014.185.195

Oesterdiekhoff, G.W., 2015. Evolution of democracy: Psychological stages and political developments in world history. Cult. Int. J. Philoso. Axiol., 12: 81-102. DOI: $10.5840 /$ cultura201512223

Oesterdiekhoff, G.W., 2016a. Cognitive modules or evolutionary stages? The discussion about the relationship between developmental and crosscultural psychology. Human Evolut., 31: 69-83.

Oesterdiekhoff, G.W., 2016b. Developmental psychology as answer to the question: Can the human disciplines achieve scientific foundations comparable to biology in consequence of Darwin, or to physics in consequence of Newton and Einstein? Eur. J. Psychol. Stud., 8: 68-107.

DOI: $10.13187 /$ ejps.2016.8.68

Oesterdiekhoff, G.W., 2016c. Child and ancient man: How to define their commonalities and differences. Am. J. Psychol., 129: 297-314. DOI: 10.5406/amerjpsyc.129.3.0295

Oesterdiekhoff, G.W., 2016d. Evolution of mentality, politics, law and social affairs during the past century. Asian J. Soc. Human Sci., 1: 53-68. DOI: $10.13187 /$ ajshs.2016.2.53

Oesterdiekhoff, G.W., 2016e. The cognitivedevelopmental approach as contribution to the explanation of the Arabian migrant's criminality. Russian J. Sociol., 4: 52-61. DOI: $10.13187 /$ rjs.2016.4.52

Oesterdiekhoff, G.W., 2016f. Theorie des Mythos. Anthropos, 111: 575-591. DOI: $10.5771 / 0257-9774-2016-2-575$

Oesterdiekhoff, G.W., 2017a. What went wrong with crosscultural psychology over the last 40 years? The developmental approach in opposition to two main ideologies of our time, cultural relativism and universalism of mind. Human Evolut., 32: 95-138. 
Oesterdiekhoff, G.W., 2017b. Evolution of morals in world history. Human Evolut., 32: 1-24.

Oesterdiekhoff, G.W., 2017c. The rise of the physical sciences in "stricto sensu". The developmental approach and the history of sciences. Phys. Int., 8: 8-23. DOI: 10.3844/pisp.2017.8.23

Oesterdiekhoff, G.W., 2018. The first scientific revolution: Developmental psychology as the fundamental theory to all human and social sciences. Human Evolut., 33: 53-86.

Oesterdiekhoff, G.W., 2019. The rise of atheism in history: The cognitive-developmental approach as explanatory model to the emergence of atheism, agnosticism, disenchantment and secularization. Human Evolut., 34: 87-113.

Piaget, J. and B. Inhelder, 1958. The Growth of Logical Thinking from Childhood to Adolescence. 1st Edn., Basic Books, New York, pp: 356.

Piaget, J. and B. Inhelder, 1969. The Psychology of the Child. 1st Edn., Basic Books, New York, ISBN-10: 1541618254, pp: 173.

Piaget, J. and R. Garcia, 1989. Psychogenesis and the History of Sciences. 1st Edn., Columbia University Press, New York. ISBN-10: 0231059922, pp: 309.

Piaget, J., 1932. The Moral Judgment of the Child. 1st Edn., The Free Press, New York, pp: 418.

Piaget, J., 1975. The Childs Conception of the World. 1st Edn., Littlefield, Adams and Co, New York.

Pinker, S., 2011. The Better Angels of our Nature: Why Violence has Declined. 1st Edn., The Viking Press, New York, ISBN-10: 1101544643, pp: 832.

Pomeranz, K., 2001. The Great Divergence. China, Europe and the Making of the Modern World Economy. 1st Edn., University Press, Princeton.

Radding, C.M., 1985. A World Made by Men. Cognition and Society 400-1200. 1st Edn., The University of North Carolina Press, Chapel Hill,

ISBN-10: 0807816647, pp: 286.

Rosenberg, S., 1988. Political Reasoning and Cognition: A Piagetian View. 1st Edn., Duke University Press, Durham and London.

Rosengren, K.S., 2000. Imagining the Impossible. 1st Edn., Cambridge University Press, London, New York.

Russo, L., 2005. The Forgotten Revolution. 1st Edn., Springer, Berlin.

Sanderson, S., 1999. Social Transformations: A General Theory of Historical Development. 1st Edn., Rowman and Littlefield Publishers, Boston, ISBN-10: 1461643422, pp: 469.

Sarrazin, T., 2018. Feindliche Übernahme: Wie der Islam den Fortschritt behindert und die Gesellschaft bedroht. 1st Edn., Finanzbuch Verlag, München, ISBN-10: 3960922957, pp: 450.
Schäfer, H., 1986. Principles of Egyptian Art: Edited by E. Brunner-Traut. 1st Edn., Griffith, Oxford.

Schultze, F., 1900. Psychologie der Naturvölker: Entwicklungspsychologische Charakteristik des Naturmenschen in intellektueller, aesthetischer, Ethischer und religiöser Beziehung. 1st Edn., Veith, Leipzig, pp: 392.

Signer, D., 2004. Die Ökonomie der Hexerei, oder, Warum es in Afrika keine Wolkenkratzer gibt. 1st Edn., Hammer Verlag, Wuppertal, ISBN-10: 3779500175, pp: 456.

Smith, A., 1776. An Inquiry into the Causes of the Wealth of Nations. 1st Edn., Strahan and Cadall, London.

Staewen, C., 1991. Kulturelle und Psychologische Bedingungen der Zusammenarbeit mit Afrikanern. 1st Edn., Ifo-Verlag, Bergisch-Gladbach.

Stern, W., 1924. Psychology of Early Childhood up to the sixth year of Age. 3rd Edn., Holt, New York, pp: 549.

Thompson, G., 1992. American Discovery: The Real Story. 1st Edn., Misty Isles Press, Seattle, ISBN-10: 0962199044, pp: 396.

Wallerstein, I., 1974. The Modern World-System. 1st Edn., Academic Press, New York, ISBN-10: 0127859209, pp: 410.

Wallon, H., 1928. La mentalité primitive et celle de l'enfant. Revue Philoso., 105: 82-105.

Weber, M., 1987. The Protestantic Ethic and the Spirit of Capitalism. 1st Edn., Routledge, New York, London.

Weiler, V., 2011. El Culto de lo Insondable o la Búsqueda de lo Cognoscible pp: 7-18: In Norbert Elias y el Problema del Desarrollo Humano, ed. by Vera Weiler. 1st Edn., Ediciones Aurora, Bogotá.

Werner, H., 1948. Comparative Psychology of Mental Development. 1st Edn., Follet, New York, pp: 564.

Wittfogel, K., 1957. Oriental Despotism: A Comparative Study of Total Power. 1st Edn., Yale University Press, pp: 556.

Wundt, W., 1914. Völkerpsychologie. 5. Band, 2. Teil. Kröner Verlag, Leipzig,

Ziégler, J., 1968. Sociologie et contestation. Paris. 